\title{
PENGARUH BENTUK ROUTING PERPIPAAN SISTEM PENDINGIN PRIMER REAKTOR TRIGA KONVERSI TERHADAP PENURUNAN AKTIVITAS N-16 DI PERMUKAAN TANGKI REAKTOR
}

\author{
V. Indriati Sri Wardhani dan Henky P. Rahardjo \\ Pusat Sains dan Teknologi Nuklir Terapan - BATAN Bandung \\ Jl. Tamansari 71 Bandung 14032 \\ Diterima editor: 30 Agustus 2016 \\ Diperbaiki: 10 Oktober 2016 \\ Disetujui untuk publikasi: 19 Oktober 2016
}

\begin{abstract}
ABSTRAK
PENGARUH BENTUK ROUTING PERPIPAAN SISTEM PENDINGIN PRIMER REAKTOR TRIGA KONVERSI TERHADAP PENURUNAN AKTIVITAS N-16 DI PERMUKAAN TANGKI REAKTOR. Program konversi reaktor TRIGA 2000 Bandung dari bahan bakar silinder menjadi bahan bakar pelat perlu perancangan sistem pendingin reaktor yang baru. Perancangan sistem pendingin reaktor yang baru tersebut diusahakan tidak banyak mengalami perubahan dari sistem pendingin reaktor yang telah ada, mengingat ruang dan tempatnya tidak mungkin diubah. Oleh karena itu perlu dilakukan analisis untuk memilih routing perpipaan sistem pendingin reaktor TRIGA pelat yang dapat memenuhi persyaratan pendinginan sistem yang sesuai dengan kondisi ruang dan tempat yang telah ada. Mengingat batasan ruang yang ada maka ada 4 (empat) kemungkinan bentuk routing yang bisa dirancang. Dari keempat kemungkinan routing tersebut kemudian dilakukan analisis waktu tempuh partikel N-16 yang memancarkan radiasi gamma $(\gamma)$ dari teras ke permukaan tangki reaktor. Penelitian dilakukan dengan mengasumsikan rapat massa $(\rho)$ fluida pendingin konstan (fluida inkompresibel), seluruh N-16 yang dihasilkan dalam teras reaktor terangkut ke permukaan tangki reaktor. Hasilnya menunjukkan bahwa routing alternatif 3 adalah yang paling optimum, karena waktu tempuhnya mendekati 5 (lima) kali waktu paruh $\mathrm{N}^{16}\left(36,7047\right.$ detik), sehingga aktivitasnya turun dari $100 \%$ menjadi $3 \%$ nya $\left(\mathrm{A} / \mathrm{A}_{0}=0,0317\right)$ dan panjang pipanya masih cukup untuk dimasukkan ke dalam ruang sistem pendingin reaktor yang tersedia.
\end{abstract}

Kata kunci: Routing, perpipaan, aktivitas N-16, waktu paruh, reaktor TRIGA pelat.

\begin{abstract}
EFFECTS OF THE PIPE ROUTING SHAPE OF THE PRIMARY COOLING SYSTEM FOR CONVERSION TRIGA REACTOR TO DECREASE N-16 ACTIVITY IN THE SURFACE REACTOR

TANK. The conversion program in 2000 Bandung TRIGA reactor fuel from the cylinder into fuel plates needs a new reactor cooling system design. The design of the new reactor cooling system are devised in such away to not much changed from the existing reactor cooling system, regarding its space and location have no possibility to change. Therefore, pipe routing analysis is required to select the plate type TRIGA reactor cooling system, to meet the cooling requirements of the system, attempted to match with the existing space and location. According to the availability of the existing space, four (4) possibilities of pipe routing can be designed. From the four possibilities of pipe routing, then analyze the travel time of particles $N-16$, which emits gamma radiation from the core to the surface of the reactor tank. Analysis was performed by assuming a constant cooling fluid density ( $\rho$ ) (incompressible fluid), the entire N-16 generated in the reactor core is transported to the surface of the reactor tank. The results show that the third alternative pipe routing is the most optimum, due to its approaching transport time is five (5) times the half-life of $N-16(36.7047 \mathrm{sec})$, so that its activities decreases from $100 \%$ to $3 \%\left(A / A_{0}=0.0317\right)$ and the pipe length is still enough to put in the available space reactor cooling system.
\end{abstract}

Keywords: Pipes, routing, $N$-16 activities, half-life, TRIGA reactor plate type. 


\section{PENDAHULUAN}

Sejak awal tahun 2016 telah dimulai perancangan sistem Reaktor TRIGA konversi yang berbahan bakar pelat untuk mengganti sistem reaktor TRIGA Bandung yang berbahan bakar silinder agar tetap beroperasi [1]. Karena reaktor TRIGA konversi ini berbahan bakar pelat maka pendingin terasnya (sistem pendingin primer) perlu dilakukan perubahan yaitu yang semula pendinginan dilakukan secara konveksi alamiah menjadi konveksi paksa dan arah aliran yang semula dari bawah ke atas menjadi dari atas ke bawah, lihat pada blok diagram Gambar 1. Pendinginan konveksi alamiah gerakan aliran fluida pendinginnya disebabkan oleh perubahan rapat massa akibat pemanasan, sedang pada konveksi paksa gerakan fluida pendinginnya dilakukan oleh pompa.
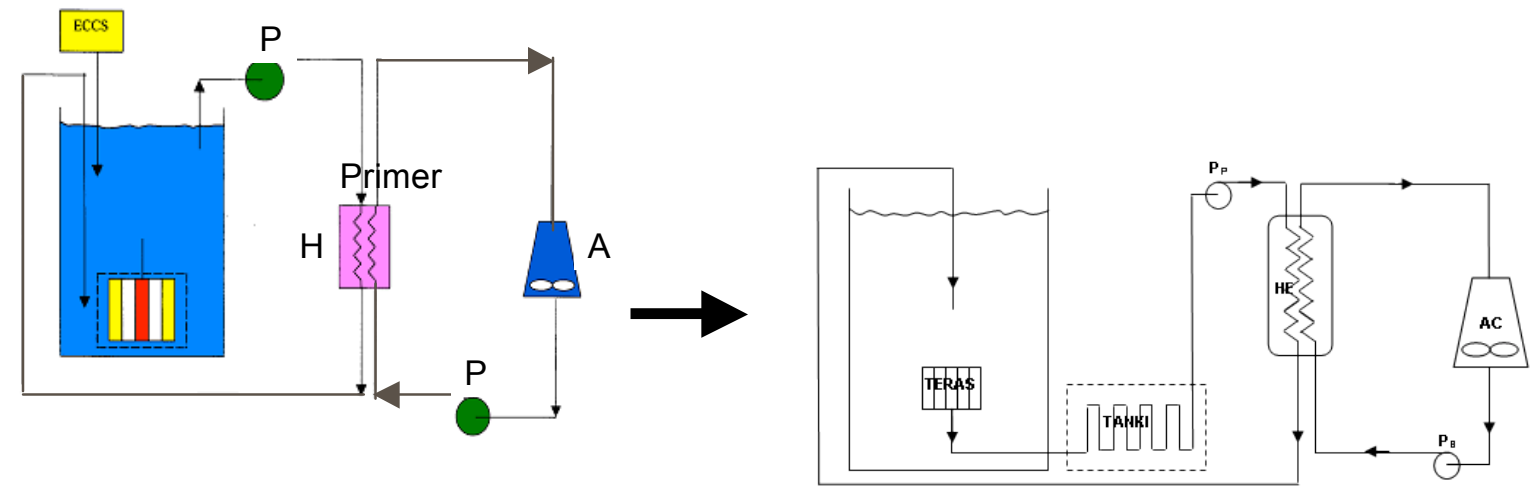

Gambar 1. Perubahan Sistem Pendinginan Teras Reaktor TRIGA [1].

Bentuk pendinginan reaktor berbahan bakar pelat dilakukan dengan mengalirkan fluida pendingin diantara celah sempit pelat bahan bakar, sehingga perlu aliran pendingin yang kuat. Aliran yang kuat hanya dapat dilakukan oleh pompa dan arah aliran dapat dibuat ke atas atau ke bawah. Untuk konveksi alamiah arah alirannya hanya dari bawah ke atas seperti pada sistem pendinginan reaktor TRIGA 2000 Bandung. Jika pada sistem reaktor TRIGA pelat arah alirannya dibuat dari bawah ke atas akan berakibat paparan radiasi di permukaan reaktor menjadi tinggi, karena adanya hasil reaksi neutron dengan air yang radioaktif seperti N-16 dan terbawa fuida pendingin bergerak ke permukaan reaktor dalam waktu yang pendek, sehingga tidak ada waktu tenggang untuk meluruh [2,3]. Disamping itu elemen bakarnya akan tertekan ke atas oleh gerakan fluida pendingin, sehingga perlu dijaga agar elemen bakar tidak bergerak ke atas selama fluida pendingin mengalir. Untuk menghindari hal itu, akan lebih tepat jika aliran dibuat dari atas ke bawah. Selain itu N-16 yang terangkut fluida pendingin harus memiliki waktu tempuh yang panjang untuk meluruh agar pada saat mencapai permukaan tangki aktivitasnya turun $[4,5]$. Oleh karena itu perlu dirancang suatu sistem perpipaan yang routing-nya cukup panjang agar waktu tempuh N-16 dari teras menuju permukaan tangki reaktornya lama sehingga aktivitas N-16 nya menjadi rendah karena akibat peluruhan. Rancangan dilakukan dengan membuat empat (4) alternatif model routing perpipaan sistem pendingin reaktor untuk menentukan routing yang optimum.

\section{TEORI}

Inti atom N-16 terjadi di dalam reaktor akibat adanya proses aktifasi neutron terhadap inti atom $\mathrm{O}-16$ yang terdapat di dalam air pendingin primer reaktor, reaksi $\mathrm{O}^{16}(\mathrm{n}, \mathrm{p}) \mathrm{N}^{16}$. Adapun reaksi ini dapat diuraikan sebagai berikut $[6,7]$ :

$$
\begin{aligned}
& { }_{8} \mathrm{O}^{16}+{ }_{0} \mathrm{n}^{1} \longrightarrow{ }_{7} \mathrm{~N}^{16}+{ }_{1} \mathrm{p}^{1} \\
& { }_{7} \mathrm{~N}^{16} \longrightarrow \mathrm{O}^{16}+{ }_{-1} \beta^{0}+\gamma
\end{aligned}
$$


Neutron yang mempunyai energi 10,1 Mev (neutron cepat) di dalam reaktor bereaksi dengan O-16 yang ada di dalam air pendingin reaktor akan terbentuk N-16 yang bersifat radioaktif. Inti atom N-16 yang terbentuk ini kemudian meluruh kembali menjadi O-16 sambil membentuk partikel $\beta$ dan memancarkan sinar $\gamma$. Akibat pancaran sinar $\gamma$ dari hasil reaksi neutron dengan O-16 yang ada di dalam air pendingin ini dapat menyebabkan aktivitas pendingin primer reaktor di atas tangki menjadi tinggi jika pendinginnya bersirkulasi dari teras ke permukaan tangki reaktor.

Aktivitas adalah perkalian antara konstanta peluruhan $(\lambda)$ dan jumlah inti radioaktif $(N)$. Jika aktivitas mula-mula $\mathrm{A}_{0}$ maka aktivitas setelah $\mathrm{t}$ detik (A) dapat dinyatakan sebagai,

$$
\mathrm{A}=\mathrm{A}_{0} \mathrm{e}^{-\lambda t}
$$

Jika aktivitasnya menjadi setengahnya, maka $\mathrm{A} / \mathrm{A}_{0}=1 / 2$ atau $1 / 2=\mathrm{e}^{-\lambda \mathrm{t}}$, maka waktu paruhnya adalah, $\mathrm{t}_{1 / 2}=\ln 2 / \lambda=0,6931 / \lambda$ dengan $\lambda$ dari N-16 adalah $0,0941 /$ detik., sehingga $t_{1 / 2} \mathrm{~N}-16=$ $0,6931 / 0,094$ detik. $=7,37$ detik [8]. Agar aktivitas air pendingin di atas tangki reaktor rendah maka waktu tempuh untuk sirkulasi dari teras ke permukaan tangki reaktor harus cukup lama. Berhubung aktivitas teras besarnya bisa bervariasi salah satunya tergantung pada daya saat operasi. IAEA menetapkan nilai batas dosis (NBD) maksimum $20 \mathrm{mSv} /$ tahun [9], sehingga meskipun aktivitas tinggi tetapi tidak melebihi NBD dianggap masih aman. Oleh karena itu diperlukan prediksi untuk memperpanjang waktu paruh peluruhannya agar harga aktivitas yang berasal dari teras menuju ke permukaan tangki reaktor menjadi jauh kecil atau tidak melewati NBD. Dengan dasar tersebut kemudian ditentukan waktu paruhnya diperpanjang menjadi 5 kali $\mathrm{t}_{1 / 2} \mathrm{~N}^{16}$ nya, dengan harapan aktivitas yang sampai di permukaan teras sudah cukup jauh lebih rendah. Jika 5 kali waktu paruh aktivitasnya masih tinggi maka harus dibatasi dengan prosedur atau batasan operasi (misal: reaktor scram).

\section{METODOLOGI}

Mempertimbangkan ruang yang tersedia di dalam gedung reaktor sudah tertentu (tetap) dan agar lebih efisien dalam melakukan konversi reaktor, maka perlu dirancang suatu sistem pendingin primer reaktor TRIGA konversi yang dapat memanfaatkan routing perpipaan yang sudah ada (sistem pendingin primer yang lama), hanya harus dibuat routing yang lebih panjang. Routing perpipaan reaktor yang lama terdiri dari 3 (tiga) bagian yaitu dari tangki reaktor ke pompa, dari pompa ke penukar panas dan dari penukar panas ke tangki reaktor. Pemikiran pemanfaatan sistem perpipaan pendingin primer yang lama dapat dilakukan dengan tetap mempertahankan routing perpipaan dari pompa ke penukar panas dan dari penukar panas ke tangki reaktor, sedang dari tangki reaktor ke pompa diubah dengan cara memutar-mutar pipa pendingin primer supaya lebih panjang agar lebih lama jarak tempuhnya, seperti terlihat pada Gambar 2. Pertambahan panjang routing pipa dapat dilakukan di dalam Bulk Shielding sehingga tidak memerlukan tambahan ruangan.
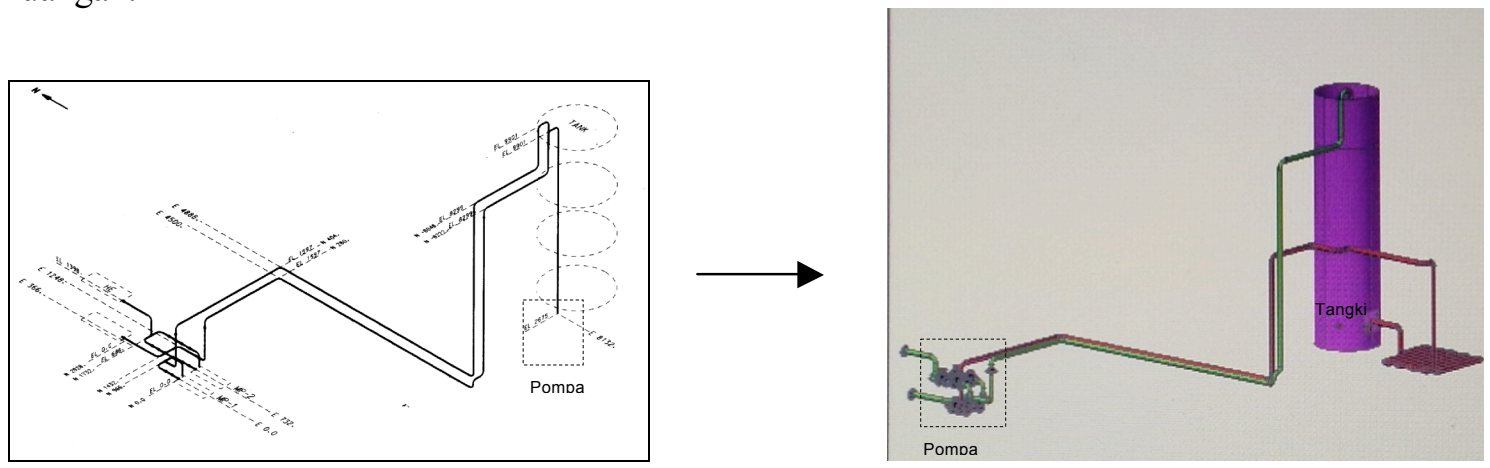

Gambar 2. Perubahan routing sistem pendingin primer reaktor dari tangki ke pompa 
Dengan batasan ruang yang ada maka ada 4 (empat) kemungkinan bentuk routing yang bisa dilakukan yaitu seperti terlihat pada Gambar 3, 4, 5 dan 6. Routing tersebut dirancang dan di analisis tegangan pipanya menggunakan perangkat lunak CAESAR II $[10,11]$. Keempat kemungkinan bentuk routing pipa tersebut, kemudian dilakukan analisis aktivitas paparan radiasi di permukaan air tangki reaktor. Aktivitas tersebut berasal dari aktivitas N-16 hasil reaksi air dengan neutron di teras reaktor. Hal tersebut dilakukan untuk memenuhi nilai batas dosis maksimum (NDB) yang telah ditetapkan IAEA [9]. Routing yang dipilih adalah yang paling optimum, yaitu lamanya waktu tempuh (t) N-16 yang dapat menurunkan aktivitas N-16 sehingga tidak banyak mengubah bentuk maupun panjang serta routing pipanya. Hal ini bertujuan supaya tidak perlu menambah ruang sistem pendingin reaktor dan alirannya cukup lambat, serta tidak mempengaruhi pendinginan sistem.

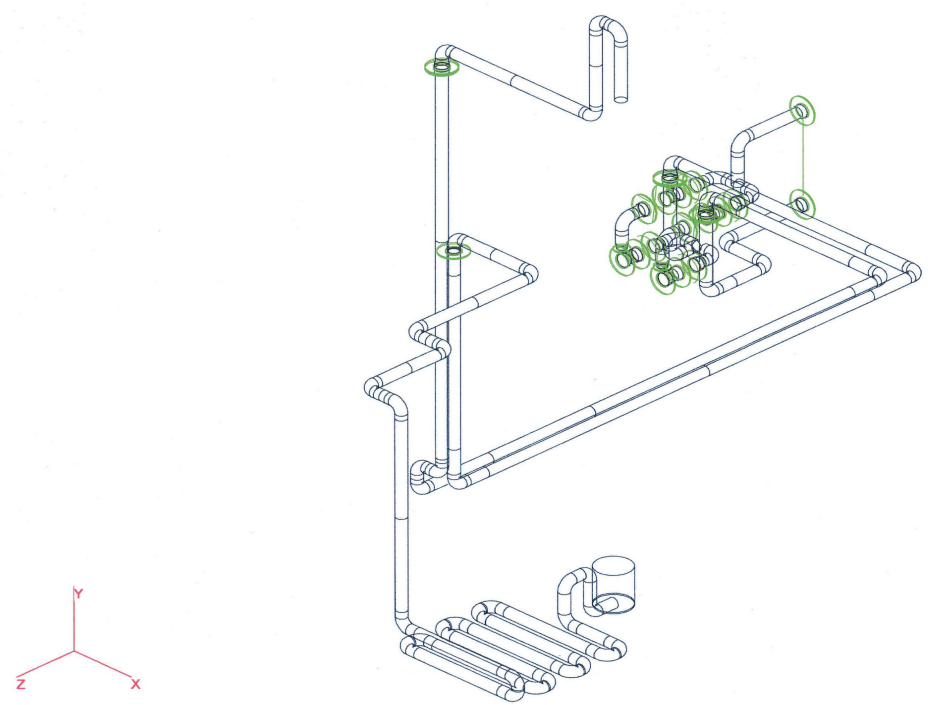

Gambar 3. Routing Sistem Pendingin Primer Reaktor Konversi Alternatif 1.

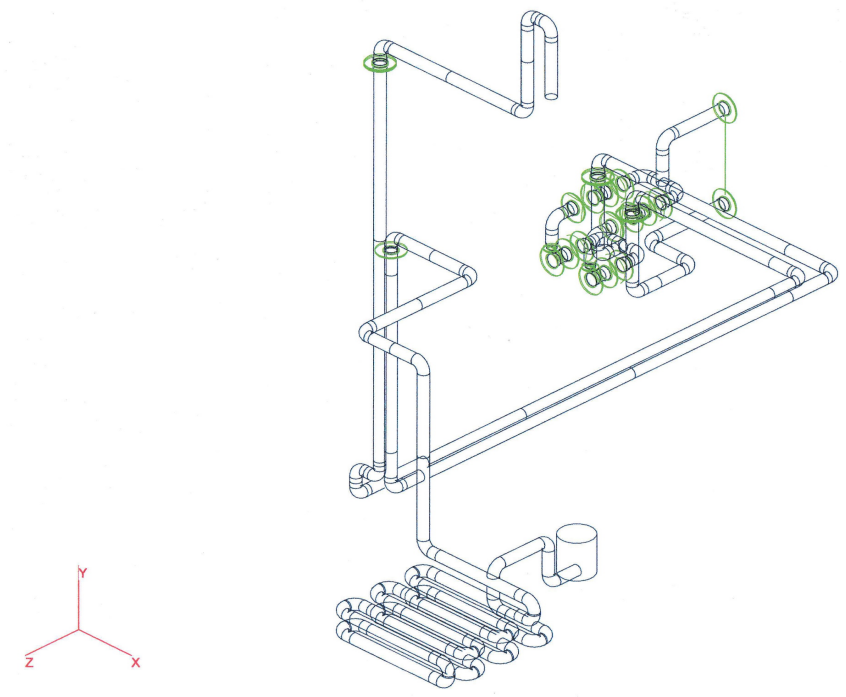

Gambar 4. Routing Sistem Pendingin Primer Reaktor Konversi Alternatif 2. 


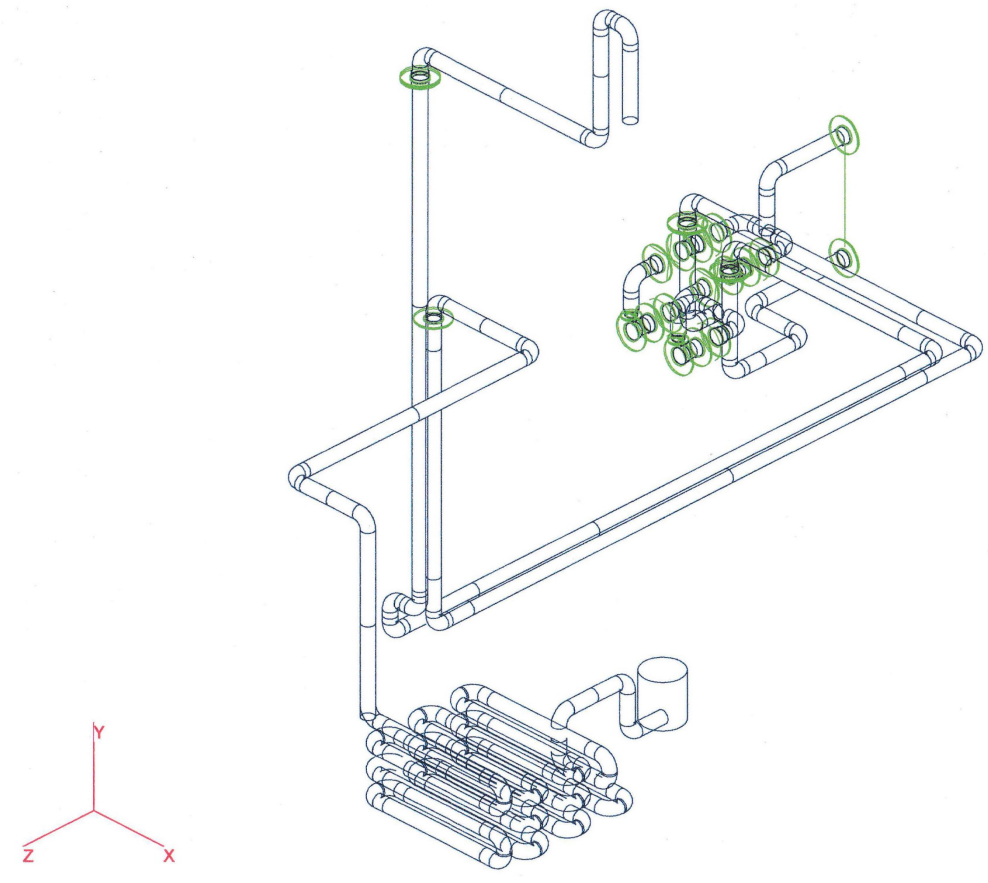

Gambar 5. Routing Sistem Pendingin Primer Reaktor Konversi Alternatif 3.
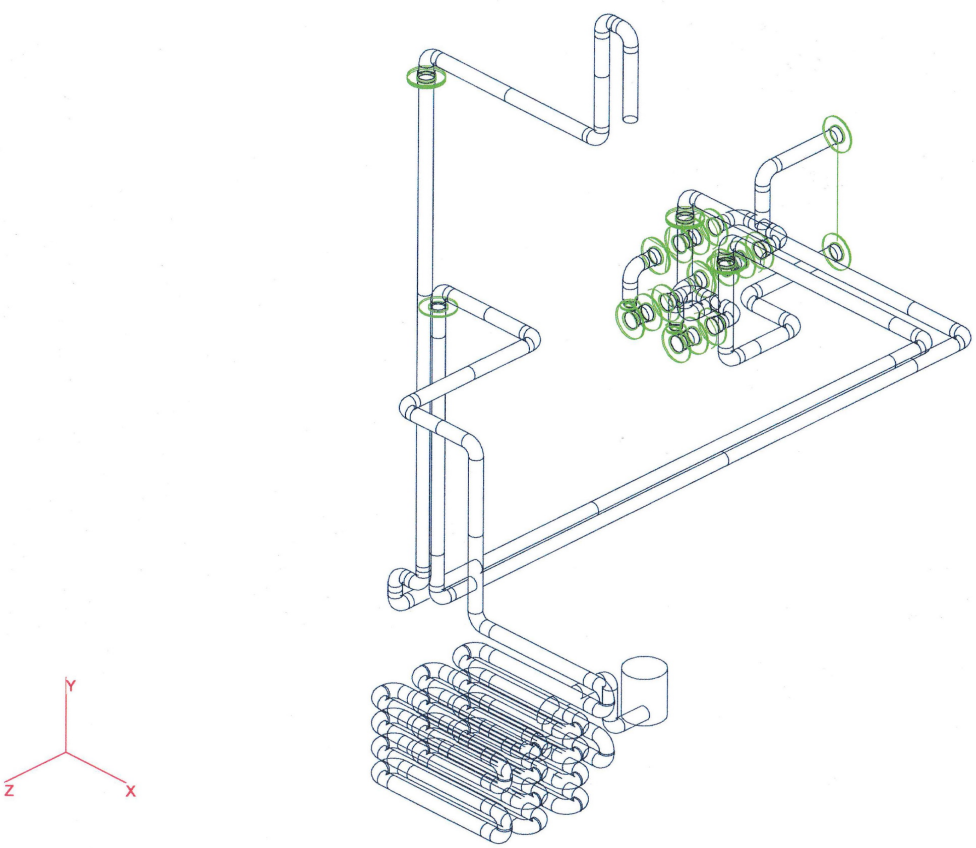

Gambar 6. Routing Sistem Pendingin Primer Reaktor Konversi Alternatif 4.

Analisis penentuan lamanya waktu tempuh (t) N-16 dilakukan dengan membuat beberapa asumsi sebagai berikut :

1. Rapat massa air pendingin dianggap konstan (fluida inkompresibel)

2. Gesekan pipa diasumsikan kecil sekali (pipa licin) 
3. N-16 hasil reaksi O-16 dengan neutron di teras reaktor bergerak menuju permukaan tangki reaktor mengikuti partikel air pendingin.

Berdasarkan ke 4 routing tersebut kemudian dapat diketahui panjang pipa keseluruhan dari teras reaktor (air pendingin keluar teras masuk ke penukar panas) masuk ke permukaan tangki reaktor (air pendingin masuk tangki, keluar dari penukar panas). Dari panjang pipa tersebut kemudian dihitung waktu tempuh N-16 sepanjang pipa tersebut berdasarkan kecepatan aliran pendinginnya. Kecepatan aliran diambil dari laju alir sistem pendingin primer reaktor TRIGA 2000 Bandung, yaitu 950 gpm. Laju alir ini ditetapkan agar pompanya masih bisa dipergunakan dan tidak perlu mengubah letak dan ruang pompanya.

Tabel 1. Hasil perhitungan head pompa.

\begin{tabular}{|c|c|c|c|c|}
\hline Notasi & Uraian & & Nilai & Satuan \\
\hline$Q$ & Kapasitas & $950 \mathrm{gpm}$ & 0,05678118 & $\mathrm{~m} 3 / \mathrm{s}$ \\
\hline $\mathrm{D}$ & Diameter & 168.275 & 0,168275 & $\mathrm{~m}$ \\
\hline A & Luas penampang pipa & & 0,022228433 & $\mathrm{~m} 2$ \\
\hline V & Kecepatan & & 2,5544 & $\mathrm{~m} / \mathrm{s}$ \\
\hline$v$ & Viskositas dinamik & & 0,000000801 & $\mathrm{~m} 2 / \mathrm{s}$ \\
\hline $\operatorname{Re}$ & Bilangan Reynold & & 536639,5065 & \\
\hline$\varepsilon$ & Epsilon & & $4,57 \mathrm{E}-05$ & $\mathrm{~m}$ \\
\hline $\mathrm{f}$ & Gesekan & & 0,014614943 & \\
\hline $\mathrm{L}_{\mathrm{S}}$ & Panjang pipa (suction) & & 89,604 & $\mathrm{~m}$ \\
\hline $\mathrm{L}_{\mathrm{D}}$ & Panjang pipa (discharge) & & 36,78687 & $\mathrm{~m}$ \\
\hline $\mathrm{K}_{\mathrm{S}}$ & Total Elbow (suction) & & 27 & \\
\hline $\mathrm{S}_{\mathrm{L}}$ & Kerugian (suction) & & 11,56777233 & $\mathrm{~m}$ \\
\hline $\mathrm{H}_{\mathrm{SS}}$ & Suction head static & & 8,56 & $\mathrm{~m}$ \\
\hline $\mathrm{K}_{\mathrm{D}}$ & Total K elbow (discharge) & & 9 & \\
\hline $\mathrm{D}_{\mathrm{L}}$ & Kerugian (discharge) & & 4,055774418 & $\mathrm{~m}$ \\
\hline $\mathrm{HE}_{\mathrm{L}}$ & Kerugian di HE & & 2 & $\mathrm{~m}$ \\
\hline $\mathrm{DT}_{\mathrm{L}}$ & Kerugian di tujuan & & 10 & $\mathrm{~m}$ \\
\hline $\mathrm{H}_{\mathrm{D}}$ & Total head (discharge) & & 16,05577442 & $\mathrm{~m}$ \\
\hline $\mathrm{H}_{\mathrm{VS}}$ & Uap beat $80{ }^{\circ} \mathrm{C}$ & & 0,0472 & bar \\
\hline $\mathrm{H}_{\mathrm{S}}$ & Total head (suction) & & $-3,00777233$ & $\mathrm{~m}$ \\
\hline $\mathrm{P}_{\mathrm{S}}$ & Tekanan Pompa (suction) & & 0,199222767 & bar \\
\hline NPSHA & Net Positive Suction Head & & 1,520227675 & bar \\
\hline $\mathrm{H}_{\mathrm{T}}$ & Total head & & 13,03554674 & $\mathrm{~m}$ \\
\hline $\mathrm{W}_{\mathrm{P}}$ & Daya Pompa & & 37,08938937 & $\mathrm{~kW}$ \\
\hline
\end{tabular}

Penetapan ini dilakukan dengan melihat bahwa head pompa yang ada masih mencukupi, yaitu dengan mempertimbangkan head ketinggian, kecepatan, perubahan tekanan masukan dan keluaran, NPSH serta kerugian lainnya, maka diperoleh head totalnya 13,035 m dan daya pompanya $37,089 \mathrm{~kW}$. Ini berarti masih di bawah head total dan daya pompa primer yang ada, yaitu $15 \mathrm{~m}$ dan $40 \mathrm{~kW}[12]$, hasil perhitungan terlihat pada tabel 1. 
Dengan diketahui waktu tempuhnya maka dapat dihitung pula fraksi penurunan aktivitas N16 nya. Adapun diagram alir analisis secara keseluruhan seperti terlihat pada Gambar 7.

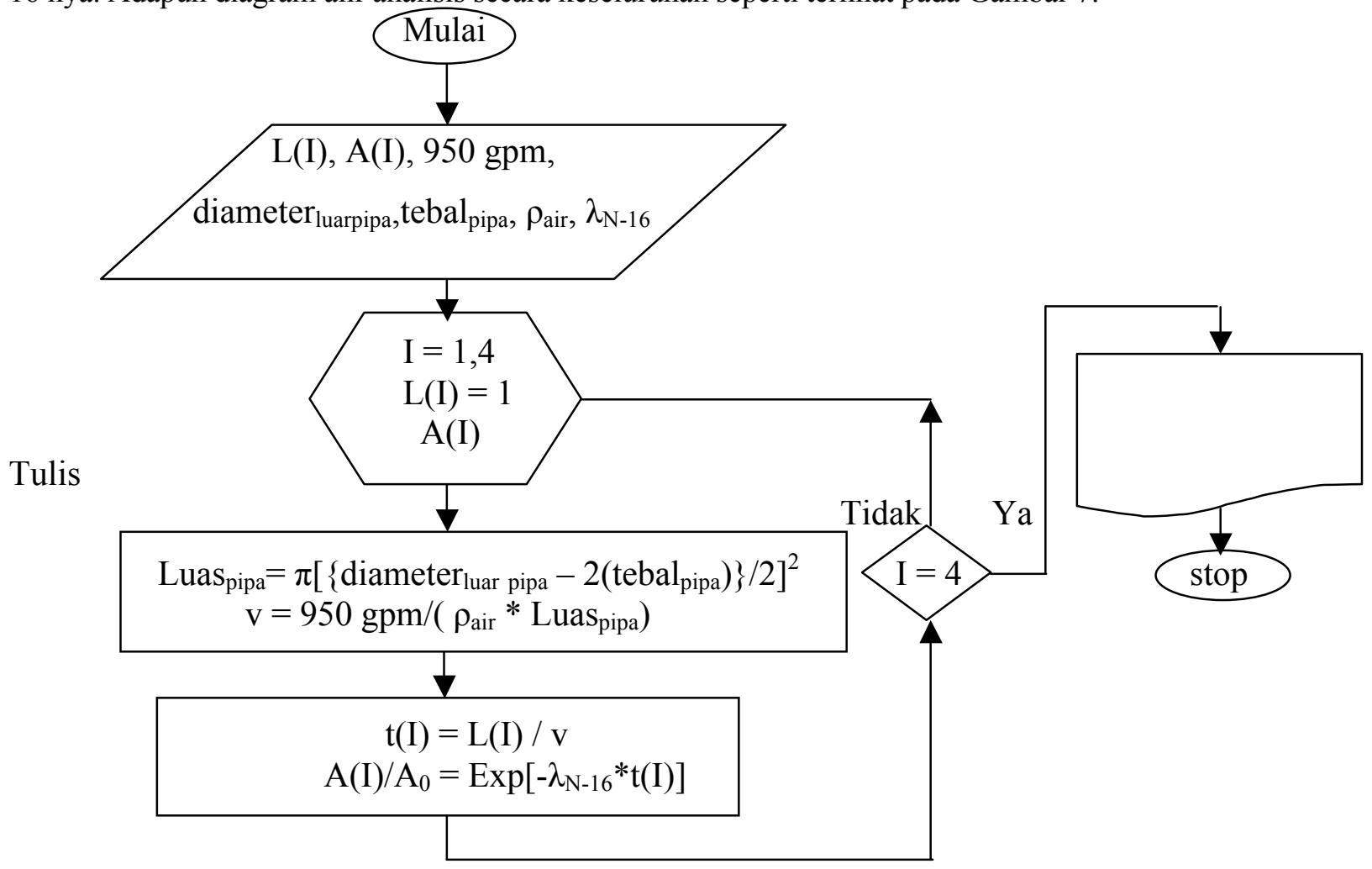

Gambar 7. Diagram Alir Analisis Waktu Tempuh dan Penurunan Aktivitas N-16.

\section{HASIL DAN PEMBAHASAN}

Hasil dari perhitungan aktivitas pada diagram alir di atas terlihat bahwa routing alternatif 1 dan 2 belum cukup memenuhi 5 (lima) kali waktu paruh N-16, sedang alternatif 3 dan 4 sudah memenuhi, lihat Tabel 2. Terlihat pula bahwa untuk diameter pipa dan laju alir yang sama, jika panjang pipa bertambah akan dapat memperlambat waktu tempuhnya, sehingga aktivitas N-16 menjadi turun jauh lebih rendah dari aktivitas awalnya (turun menjadi 0,0317), lihat pada Tabel 2 dan kurva Gambar 8.

Tabel 2. Hasil Analisis Aktivitas N-16

\begin{tabular}{cccccc}
\hline $\begin{array}{c}\text { Alternatif Routing } \\
\text { Pipa }\end{array}$ & $\begin{array}{c}\text { Diameter } \\
\text { luar Pipa } \\
\text { (in) }\end{array}$ & $\begin{array}{c}\text { Laju Alir } \\
(\mathrm{gpm})\end{array}$ & $\begin{array}{c}\text { Panjang } \\
\text { Total Pipa } \\
(\mathrm{m})\end{array}$ & $\begin{array}{c}\text { Waktu } \\
\text { tempuh(detik) N }\end{array}$ & $\begin{array}{c}\text { FRAKSI } \\
\text { Aktivitas } \\
\text { (A/Ao) }\end{array}$ \\
\hline 1 & 6,625 & 950 & 89,604 & 27,854 & 0,0729 \\
2 & 6,625 & 950 & 102,199 & 31,7693 & 0,0505 \\
3 & 6,625 & 950 & 118,076 & 36,7047 & 0,0317 \\
4 & 6,625 & 950 & 130,704 & 40,63 & 0,0219 \\
\hline
\end{tabular}




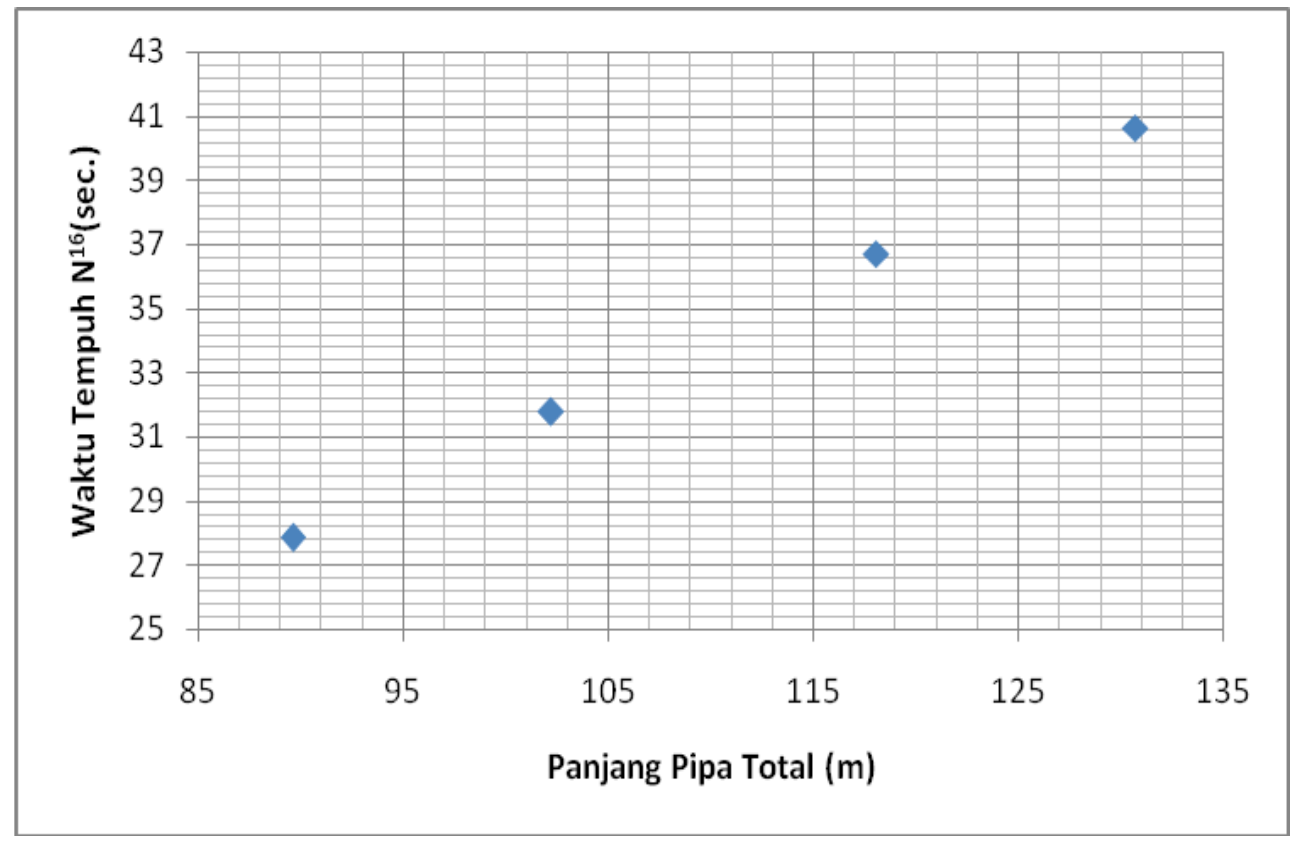

Gambar 8. Kurva hubungan Panjang Pipa Total dengan Waktu Tempuh N-16.

Disini terlihat bahwa yang mengakibatkan turunnya aktivitas adalah panjang pipa, sehingga jika panjang pipa bertambah akan menyebabkan daya yang dibutuhkan pompa juga berubah. Oleh karena itu dilakukan perhitungan head dan daya pompa untuk ke empat routing pipa dan dipilih routing yang paling optimum menghasilkan head dan daya pompa yang dapat terpenuhi oleh pompa yang lama, yaitu pompa yang telah digunakan oleh Reaktor TRIGA 2000 Bandung. Hasilnya seperti terlihat pada Tabel 3, kemudian dipilih bahwa routing alternatif III adalah yang paling optimum, dengan head dan daya pompanya adalah $13,857 \mathrm{~m}$ dan $39,429 \mathrm{~kW}$ masih di bawa batas $15 \mathrm{~m}$ dan $40 \mathrm{~kW}$ [12]. Untuk alternative IV walaupun headnya masih terpenuhi tetapi daya pompanya lebih besar dari $40 \mathrm{~kW}$, jadi tidak terpenuhi.

Tabel 3. Hubungan antara perubahan panjang pipa dengan head dan daya pompa

\begin{tabular}{cccc}
\hline $\begin{array}{c}\text { Alternatif } \\
\text { Routing }\end{array}$ & $\begin{array}{c}\text { Panjang Pipa } \\
(\mathrm{m})\end{array}$ & $\begin{array}{c}\text { Head } \\
(\mathrm{m})\end{array}$ & $\begin{array}{c}\text { Daya Pompa yang } \\
\text { dibutuhkan }(\mathrm{kW})\end{array}$ \\
\hline I & 89,604 & 13,035 & 37,089 \\
II & 102,199 & 13,399 & 38,124 \\
III & 118,076 & 13,857 & 39,429 \\
IV & 130,704 & 14,222 & 40,467 \\
\hline
\end{tabular}

Pada laju alir 950 gpm perlu diperhitungkan kemampuan pendinginan terasnya secara termohidraulik, supaya tidak perlu ada perubahan pompa penggeraknya.

Demikian pula hubungan antara waktu tempuh dengan fraksi aktivitas N-16 pada Gambar 9 terlihat bahwa jika waktu tempuhnya pendek penurunan aktivitas N-16 nya rendah atau dengan kata lain fraksi aktivitasnya tinggi, dan jika waktu tempuhnya panjang maka penurunan aktivitas $\mathrm{N}$ 16 nya besar atau fraksi aktivitasnya rendah. Dari semua hasil tersebut kemudian dipilih routing yang paling optimum memenuhi syarat, yaitu yang waktu tempuhnya memenuhi tetapi panjangnya tidak terlalu panjang sehingga bisa masuk ke ruang reaktor yang tersedia (tidak perlu menambah ruangan sistem pendingin). Dengan demikian alternatif 3 adalah yang paling optimum, waktu tempuhnya paling mendekati 5 (lima) kali waktu paruh N-16, yaitu 36,7047 detik, sehingga aktivitasnya turun dari $100 \%$ menjadi $3 \%$ nya $\left(\mathrm{A} / \mathrm{A}_{0}=0,0317\right)$ dan panjang pipanya masih cukup untuk dimasukkan ke dalam ruang sistem pendingin reaktor yang tersedia. 


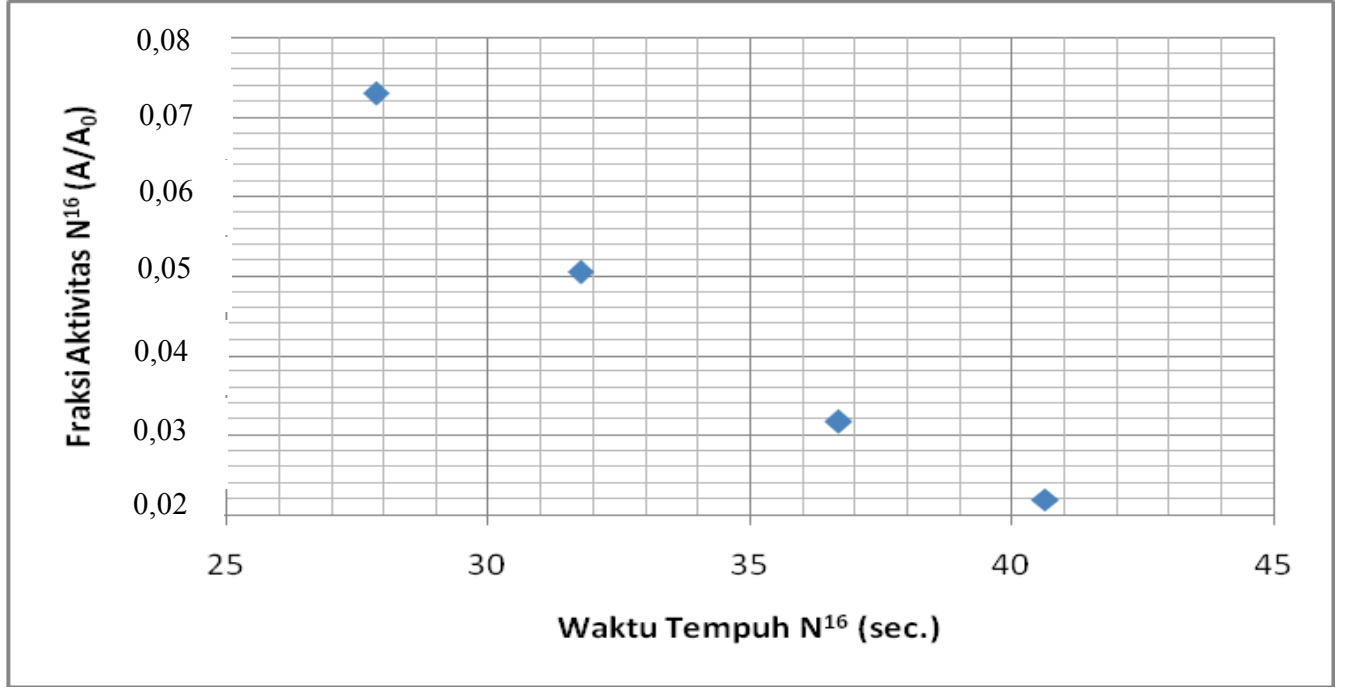

Gambar 9. Kurva hubungan Waktu Tempuh dengan Fraksi Aktivitas N-16.

\section{KESIMPULAN}

Berdasarkan hasil yang diperoleh dari analisis di atas, maka dapat disimpulkan bahwa routing alternatif I dan II belum cukup memenuhi 5 (lima) kali waktu paruh N-16, sedang alternatif III dan IV sudah cukup memenuhi (dengan waktu paruh N-167,37 detik), tetapi alternatif IV daya pompa yang ada tidak cukup memenuhi, sehingga yang paling optimum adalah alternatif III. Routing alternatif 3 waktu tempuhnya paling mendekati 5 (lima) kali waktu paruh N-16, yaitu 36,7047 detik, sehingga aktivitasnya turun dari $100 \%$ menjadi $3 \%$ nya $\left(\mathrm{A} / \mathrm{A}_{0}=0,0317\right)$ dan panjang pipanya masih cukup untuk dimasukkan ke dalam ruang sistem pendingin reaktor yang tersedia.

\section{DAFTAR PUSTAKA}

1. Henky P. Rahardjo, V. Indriati Sri Wardhani. The Critical Point of Reactor TRIGA 2000 Bandung to TRIGA Reactor Fuel Plates. The $15^{\text {th }}$ Seminar sains and nuclear technology Batan-Bandung. 2015. pp.137-142.

2. P.Ortiz-Lopez, G. Rajan, E.B. Padgorsak. Radiation Protection and Safety in Radiotherapy Chapter 16. 2012. pp.549-609.

3. Kebwaro J.M., Zhao Y., He C. Simulation of $(16) \mathrm{O}(\mathrm{n}, \mathrm{p})(16) \mathrm{N}$ Reaction Rate and Nitrogen 16 Inventory in a High Performance Light Water Reactor with One Pass Core. International journal of Applied radiation and isotopes. 2014; 94: 35-39.

4. Tufic Madi Fihli, Jose Patricio Nahuel, Antonio Carlos Iglesias Rodrigues. Application of Prompt Gamma Source for N-16 Detector System Calibration. International Nuclear Atomic Conferecce-INAC. 2011. pp. 1-5.

5. Pierson B.D., Griffin H.C., Flaska M., Katalenich J.A., Kitchen B.B., Pozzi S.A. Benchmarking of Repeatability of a Pneumatic Cyclic Neutron Activation Analysis Facility Using $16 \mathrm{O}(\mathrm{n}, \mathrm{p}) 16 \mathrm{~N}$ for Nuclear Forensics. International journal of Applied radiation and isotopes. 2015; 96. pp. 20-26.

6. Nahid Sadeghi. Estimation of Reactor Power Using N-16 Production Rate and its Radiation Risk Assessment in Teheran Research Reactor (TRR). J. Nuclear engineering and design. 2010; 240. pp. 3607-3610. 
7. Chistopher Earls Brennen. Thermo-hydraulics of Nuclear Reactors Chapter 2.4-2.5. Dankar publishing company. 2014. pp. 14-18.

8. John R. Lamarsh, Anthony J. Baratta. Introduction to Nuclear Engineering Pearson Education Limited. 2013. pp. 21-25.

9. IAEA Safety Standard Radiation Protection and Safety of Radiation Source: International Basic Safety Standard. 2011.

10. Ms.Prachi N. Tanbe, Prof.Dr.K.K.Dhande, Prof.N.I.Jamadar. Flexibility and Stress Analysis of Piping System using CAECAR II-Case study. J. Engineering research and technology. 2014; 3. pp. 370-374.

11. Jelene Priss, Ivan Klevtsov. The Program Strength Calculation in Pipe Line. International Symposium $10^{\text {th }}$ Tropical Problems in the Field of Electrical and Power Engineering. 2011. pp. 209-212.

12. Laporan Analisis Kecelakaan: Reaktor TRIGA 2000 Bandung Revisi. 3 LP-01-RE-001. 2006. pp. 11-19. 